\title{
PENGARUH PUPUK HAYATI DENGAN KOMPOSISI MIKROORGANISME YANG BERBEDA TERHADAP PERTUMBUHAN TANAMAN
}

\author{
Effect of Biofertilizers with Different Composition of Microorganisms \\ on Maize Plant Growth
}

\author{
Amalia Puji Cahyani, Asri Pirade Paserang, Meryany Ananda dan Wahyu Harso, \\ Jurusan Biologi Fakultas Matematika dan IImu Pengetahuan Alam Universitas Tadulako
}

Keywords:

Biofertilizer, Composition, Growth

Kata kunci :

Komposisi, Pertumbuhan, Pupuk Hayati

\begin{abstract}
Biofertilizer can be used to replace chemical fertilizer so that soil quality is maintained and soil pollution can be avoided. The study aimed to determine the effect of biofertilizers with different compositions of microorganisms on the growth of maize plants. The research was carried out in a greenhouse. Maize plants were fertilized by two kinds of biofertilizers with different compositions of microorganisms. The first biofertilizer contained Azotobacter sp, Azospirillum $\mathrm{sp}$, Rhizobium sp, Trichoderma sp, and Lactobacillus sp, and the second biofertilizer contained Strenotrophomonas sp. and Paenibacillus polymyxa. As controls, maize plants were fertilized by sterilized those biofertilizers. The results showed that the second biofertilizer increased the dry weight of the maize plant. Meanwhile, the first biofertilizer did not increase it. Several things must be considered in the application of biofertilizers, such as the composition of microorganisms, type of plant, level of fertilization, and the method of applying fertilizer to the plant.
\end{abstract}

Corresponding Author : wahyuharso@gmail.com 


\section{PENDAHULUAN}

Jagung merupakan salah satu komoditas unggulan pertanian. Selain sebagai pengganti beras, jagung juga dibutuhkan untuk mencukupi kebutuhan pakan ternak (Edi, 2019). Pada pertanian konvensional pupuk kimia biasanya digunakan untuk meningkatkankan produktivitas tanaman (Santos et al., 2012). Penggunan pupuk kimia dalam jangka panjang akan menurunkan kadar bahan organik dalam tanah, merusak struktur tanah sehingga menurunkan kualitas tanah (Simanjuntak dkk., 2013). Selain itu penggunaan pupuk kimia juga akan mencemari lingkungan karena pupuk kimia sering mengandung logam berat seperti $\mathrm{Hg}, \mathrm{Cd}, \mathrm{As}, \mathrm{Pb}, \mathrm{Cu}, \mathrm{Ni}$ (Savci, 2012).

Untuk mengurangi dampak negatif penggunaan pupuk kimia dalam jangka panjang terhadap tanah, pupuk hayati atau biofertilizer dapat digunakan sebagai pengganti pupuk kimia dalam meningkatkan pertumbuhan dan produksi tanaman. Pupuk hayati adalah pupuk yang berasal dari biomasa berbagai mikroorganisme tanah yang dapat berfungsi sebagai penyedia hara dalam tanah sehingga mudah diserap oleh tanaman (Nugraha dkk., 2014). Dengan menggunakan pupuk hayati diharapkan mampu untuk mempertahankan kualitas tanah dan mengurangi pencemaran (Vandenberghe et al., 2017).
Mikroorganisme yang biasa digunakan sebagai pupuk hayati adalah Bacillus, Pseudomonas, Rhizobium, Azosprillum, Azotobacter, Mikoriza dan Trichoderma (Sudiarti, 2017). Mekanisme yang terlibat dalam proses mikroorganisme sebagai pupuk hayati adalah fiksasi nitrogen, meningkatkan kelarutan mineral dan fosfat, memproduksi enzim yang mendegradasi makromolekul (amilase, protease, dan hemiselulase), menghasilkan fitohormon (auksin, gibererlin dan sitokinin), dan senyawa volatil yang mestimulasi pertumbuhan (etilen dan 2.3 butanediol) (Borris, 2011). Maulana dkk (2015) melaporkan bahwa pertumbuhan dan hasil tanaman jagung ditingkatkan dengan menggunakan pupuk hayati yang mengandung Rhizobium sp, Azospiriluum $\mathrm{sp}$, Aziotobacter sp, Pseudomonas sp, Bacillus sp, Lactobacillus sp, Accharomyses sp, Trichoderma dan Actinomycetes,

Tujuan penelitian ini adalah untuk mengetahui pengaruh pupuk hayati yang memiliki komposisi mikroorganisme yang berbeda terhadap pertumbuhan tanaman jagung

\section{BAHAN DAN METODE}

\section{Bahan}

Tanaman uji yang digunakan adalah tanaman jagung manis SD3 IPB. Pupuk hayati yang digunakan adalah dua macam pupuk hayati komersial yang memiliki komposisi mikroorganisme yang berbeda. 
Komposisi mikroorganisme yang digunakan dapat dilihat pada tabel 1.

Tabel 1. Komposisi mikroorganisme dari dua pupuk hayati yang digunakan dalam penelitian Produk Bentuk Komposisi (cfu/ml)

\begin{tabular}{|c|c|c|c|}
\hline Produk & Bentuk & Komposisi (c & \\
\hline \multirow{5}{*}{$X$} & \multirow{5}{*}{ Cair } & Azotobacter sp & $1.1 \times 10^{8}$ \\
\hline & & Azospirillum $\mathrm{sp}$ & $3.4 \times 10^{8}$ \\
\hline & & Rhizobium sp & $4.6 \times 10^{8}$ \\
\hline & & Trichoderma sp & $1.0 \times 10^{8}$ \\
\hline & & Lactobacillus sp & $1.3 \times 10^{7}$ \\
\hline \multirow{2}{*}{ Y } & \multirow{2}{*}{ Cair } & Strenotrophomonas sp & $1.0 \times 10^{\prime}$ \\
\hline & & Paenabacillus polymyxa & $1.0 \times 10^{7}$ \\
\hline
\end{tabular}

\section{Metode}

Penelitian dilakukan dengan menggunakan Rancangan Acak Lengkap yang teridiri dari dua faktor. Faktor pertama adalah tanpa (X0 dan Y0) dan dengan pemberian pupuk hayati (X1 dan Y1) dan faktor kedua adalah komposisi dari pupuk hayati yang digunakan (pupuk hayati dari merek $\mathrm{X}$ yang terdiri dari Azotobacter sp, Azospirillum sp, Rhizobium sp, Trichoderma sp, Lactobacillus $\mathrm{sp}$ dan pupuk hayati dari merek $Y$ terdiri dari Strenotrophomonas $\mathrm{sp}$. dan Paenibacillus polymyxa.

\section{Penyiapan media tanam}

Tanah yang digunakan merupakan tanah jenis entisol yang diperoleh dari kampus Universitas Tadulako. Tanah diambil dengan kedalaman 0-20 cm. Tanah diayak dengan ayakan ukuran $4 \mathrm{~mm}$ dan diaduk secara homogen sebelum dimasukkan ke dalam polybag. Sebanyak $4 \mathrm{~kg}$ tanah dicampur dengan $150 \mathrm{~g}$ pupuk hijau dari daun lamtoro (Leucaena leucephala) yang sudah dikeringkan dimasukkan ke dalam polybag dengan ukuran $30 \times 25 \mathrm{~cm}$.

\section{Penanaman}

Masing masing polybag diberi air dengan kelembaban $100 \%$ kapasitas lapang tanah. Kemudian 3 biji jagung dimasukkan ke dalam masing masing polybag dengan kedalaman yang sama. Masing-masing polybag diletakan di dalam rumah kaca secara acak. Setelah berumur 1 minggu setelah tanam masing masing polybag disisakan 1 benih tanaman jagung yang memiliki tingkat keseragaman yang tinggi terhadap tanaman jagung pada polybag yang lain. 


\section{Pemberian pupuk hayati}

Sebanyak $10 \mathrm{ml}$ pupuk hayati ditambahkan untuk masing masing polybag. Untuk perlakuan tanpa pemberian pupuk hayati, masing masing polybag diberi $10 \mathrm{ml}$ pupuk hayati yang telah disterilisasi dengan menggunakan autoklaf pada suhu $121^{\circ} \mathrm{C}$ selama 30 menit. Pemberian dilakukan dua kali seminggu sesuai dengan rekomendasi dari pupuk hayati yang digunakan.

\section{Pemeliharaan}

Kandungan air pada tanah sampai umur dua minggu dipertahankan pada 100\% kapasitas lapang. Setelah umur lebih dari dua minggu kadar air dalam tanah dipertahankan pada 60\% kapasitas lapang setiap 3 hari sekali sampai akhir penelitian. Penambahan air sesuai kapasitas lapang yang ditentukan dilakukan secara gravimetrik. Air yang ditambahkan adalah air yang sudah disterilisasi dengan memanaskan sampai mendidih untuk menghindari kontaminasi dari mikroorganisme lain. Setiap tiga hari sekali posisi masing masing polybag dirubah secara acak.

\section{Pemanenan}

Pemanenan dilakukan saat tanaman jagung menunjukkan adanya anthesis (berbunga). Bagian tajuk dipanen dengan memotong pangkal batang $0.5 \mathrm{~cm}$ dari permukaan tanah. Akar dipanen dengan mencuci akar dengan air mengalir.

\section{Pengamatan}

Tinggi tanaman diukur dengan mengukur panjang dari pangkal batang sampai ruas batang terakhir sebelum bunga.

Jumlah daun dihitung dengan menghitung seluruh helaian daun pada setiap tanaman.

Luas daun dihitung dengan membuat replika semua daun pada tiap tiap tanaman di kertas HVS yang sudah diketahui berat perlembarnya kemudian replika tersebut dipotong dan kemudian ditimbang. Luas permukaan daun adalah berat kertas dari replika dibagi dengan berat kertas HVS ukuran $1 \times 1 \mathrm{~cm}$.

Berat kering tajuk dan akar diukur menggunakan timbangan. Sebelum diukur tajuk dan akar dikeringkan dalam oven selama $65^{\circ} \mathrm{C}$ selama 72 jam.

Berat kering total diukur dengan menjumlahkan berat kering tajuk dan berat kering akar.

\section{Analisis data}

Data yang diperoleh dianalisis dengan menggunakan Twoway Anova dengan menggunakan program JAMOVI versi 2.2.2. Pada setiap perlakuan, pengaruh perlakuan dikatakan nyata terhadap parameter pengamatan bila $\mathrm{P}<0.05$.

\section{HASIL}

Berdasarkan hasil analisis statistik didapatkan bahwa pemberian pupuk hayati tidak berpengaruh nyata terhadap parameter pertumbuhan tanaman yang diamati (Tabel 2). Meskipun demikian 
rerata tinggi tanaman (Gambar 1), jumlah daun (Gambar 2) cenderung lebih tinggi pada tanaman yang diberi pupuk hayati dibandingkan tanpa pemberian pupuk hayati. Pemberian pupuk hayati $X$ dengan komposisi mikroorganisme Azotobacter sp, Azospirillum sp, Rhizobium sp, Trichoderma $\mathrm{sp}$, Lactobacillus sp lebih meningkatkan tinggi tanaman dan jumlah daun dibandingkan dengan pupuk hayati $Y$ dengan komposisi mikroorganisme Strenotrophomonas sp. dan Paenibacillus polymyxa.
Akan tetapi pupuk hayati $\mathrm{Y}$ lebih meningkatkan berat kering tajuk dan akar tanaman jagung dibandingkan dengan pupuk hayati $X$ meskipun secara statistik tidak berbeda nyata (Gambar 4 dan 5). Sehingga tanaman yang diberi pupuk hayati $Y$ memiliki rerata total berat kering yang lebih tinggi dibandingkan dengan rerata total berat kering tanaman yang tanpa diberi pupuk hayati (Gambar 6)

Tabel 2. Hasil analisis statistik perlakuan terhadap parameter pengamatan

\begin{tabular}{lccc}
\hline \multirow{2}{*}{ Parameter } & \multicolumn{3}{c}{ Signifakansi (nilai P) } \\
\cline { 2 - 4 } & $\begin{array}{c}\text { Pemberian } \\
\text { Biofertilizer }\end{array}$ & $\begin{array}{c}\text { Komposisi } \\
\text { Biofertilizer }\end{array}$ & Interaksi \\
\hline $\begin{array}{l}\text { Tinggi } \\
\text { Tanaman }\end{array}$ & 0.309 & 0.585 & 0.464 \\
\hline $\begin{array}{l}\text { Jumlah } \\
\text { daun }\end{array}$ & 0.197 & 0.381 & 1.00 \\
\hline Luas daun & 0.313 & 0.410 & 0.726 \\
\hline $\begin{array}{l}\text { Berat } \\
\text { kering tajuk }\end{array}$ & 0.896 & 0.671 & 0.387 \\
\hline $\begin{array}{l}\text { Berat } \\
\text { kering akar }\end{array}$ & 0.510 & 0.673 & 0.354 \\
\hline $\begin{array}{l}\text { Total berat } \\
\text { kering }\end{array}$ & 0.780 & 0.630 & 0.321 \\
\hline
\end{tabular}




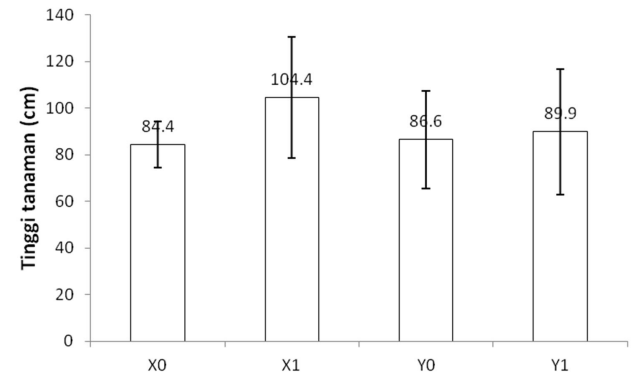

Gambar 1. Tinggi tanaman jagung yang diberi pupuk hayati dengan komposisi Azotobacter sp, Azospirillum sp, Rhizobium sp, Trichoderma sp, Lactobacillus sp (X1) dan Strenotrophomonas $\mathrm{sp}$

Paenibacillus polymyxa (Y1) serta tanpa pemberian biofertilizer (X0 dan Y0). Nilai yang ditampilkan adalah rata rata \pm simpangan baku.

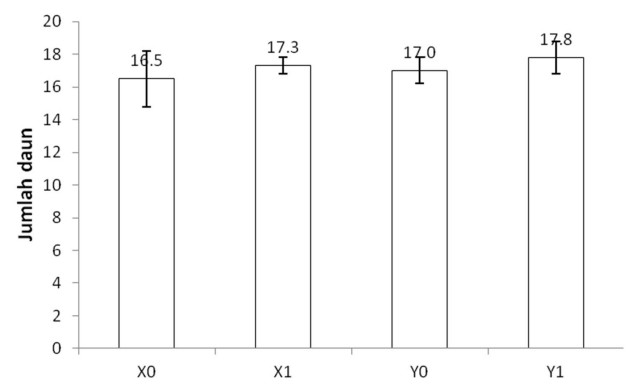

Gambar 2. Jumlah daun tanaman jagung.
Keterangan selanjutnya seperti
keterangan pada Gambar 1.

Pemberian pupuk hayati $X$ cenderung menurunkan luas daun (Gambar 3), berat kering tajuk (Gambar 4), dan berat kering akar (Gambar 5).

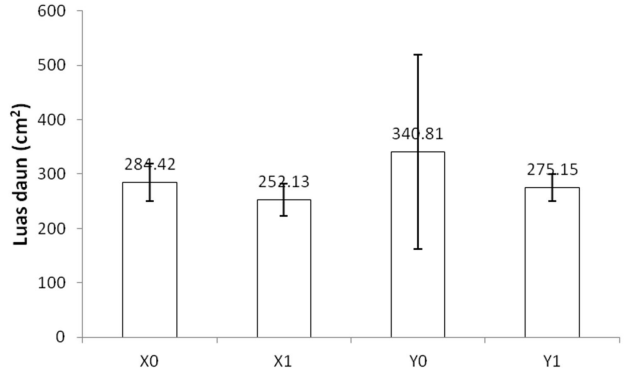

Gambar 3. Luas daun tanaman jagung. Keterangan selanjutnya seperti keterangan pada Gambar 1.

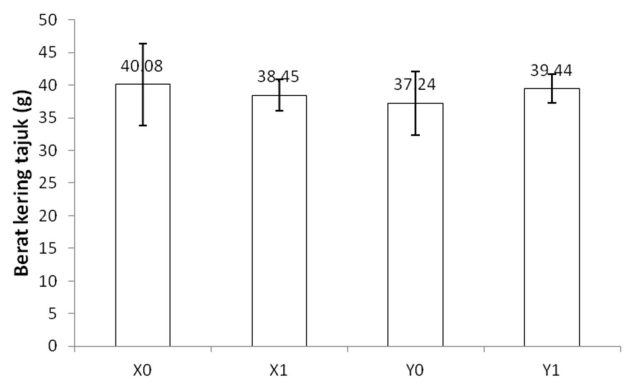

Gambar 4. Berat kering tajuk tanaman jagung. Keterangan selanjutnya seperti keterangan pada Gambar 1.

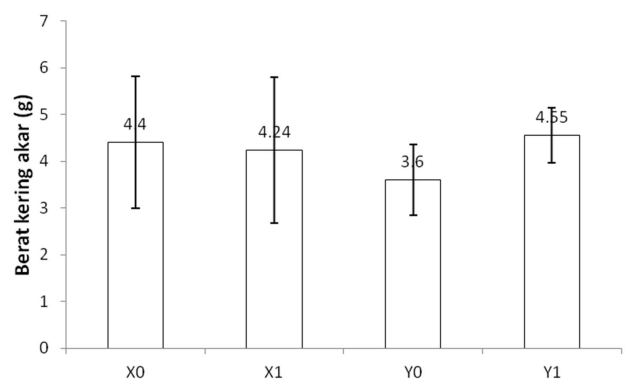

Gambar 5. Berat kering akar tanaman jagung. Keterangan selanjutnya seperti keterangan pada Gambar 1. 


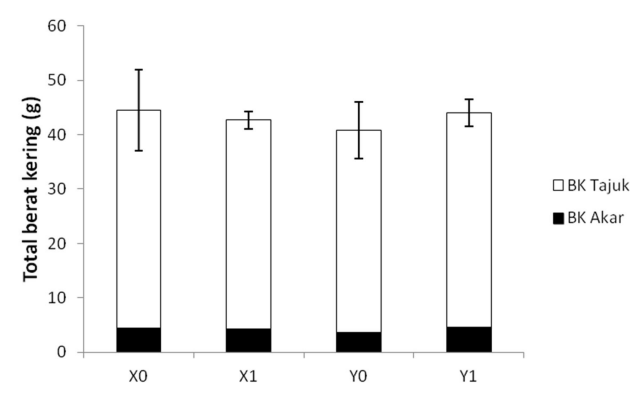

Gambar 6. Total berat kering tanaman jagung. Keterangan selanjutnya seperti keterangan pada Gambar 1.

\section{PEMBAHASAN}

Secara umum mekanisme mikroorganisme yang digunakan sebagai pupuk hayati dalam meningkatkan pertumbuhan adalah melalui fiksasi nitrogen, meningkatkan kelarutan mineral dan fosfat, memproduksi enzim yang mendegradasi makromolekul, menghasilkan fitohormon dan menghasilkan senyawa volatil yang mestimulasi pertumbuhan (Borris, 2011). Adapun peran dari masing-masing mikroorganisme dalam pupuk hayati $X$ adalah sebagai berikut: $a$. Azotobacter $s p$ mampu mengikat nitrogen yang ada di udara sehingga berkontribusi terhadap ketersediaan nitrogen di dalam tanah setelah terjadi kematian sel bakteri tersebut. Selain itu juga mampu menghasilkan auksin, sitiokinin dan giberelin (Jnawali et al., 2015), b. Azospirillum sp mampu untuk mengikat nitrogen di udara dan menghasilkan fitohormon terutama auksin (Fukami et al., 2018), c. Trichoderma sp mampu mempercepat proses dekomposisi karena mampu mendegradasi dinding sel (Waghunde et al., 2016), d. Lactobacillus sp dapat menghasilkan auksin (AfanadorBarajas et al., 2021). Adapun peran mikroorganisme dari pupuk hayati $Y$ adalah:

a. Stenotrophomonas $\mathrm{sp}$ mampu melarutkan fosfat inorganik, menghasilkan auksin dan siderofor. Siderofor berperan untuk membantu penyerapan Fe (Patel and Saraf, 2017),

b. Paenibacillus polymyxa mampu mengikat nitrogen di udara dan menghasilkan auksin (Jeong et al., 2019).

Parameter pertumbuhan yang representatif adalah berat kering tanaman karena berat kering tanaman merupakan gabungan dari semua peristiwa fisiologis tanaman (Sitompul dan Guritno, 1995). Berdasarkan berat kering tanaman yang diukur, pupuk hayati $Y$ lebih meningkatkan pertumbuhan dibandingkan dengan pupuk hayati $X$. Pemberian pupuk hayati $X$ cenderung menurunkan berat kering tanaman.

Aplikasi pupuk hayati tidak selalu meningkatkan pertumbuhan tanaman (Afanador-Barajas et al., 2021). Beberapa faktor yang harus diperhatikan dalam penggunaan pupuk hayati adalah komposisi dari mikroorganisme yang digunakan (Laditi et al., 2011) jenis tanaman yang dipilih, tingkat dan jenis pemupukan pada media tanam (Vandenberghe et al., 2017). Aplikasi pupuk hayati tanpa pemberian 
unsur hara justru akan menurunkan pertumbuhan tanaman karena mikroorganisme dalam pupuk hayati berkompetisi dengan tanaman terhadap unsur hara. Tidak berfungsinya mikroorganisme pada pupuk hayati dalam meningkatkan pertumbuhan tanaman juga bisa disebabkan oleh sulitnya mikroorganisme melakukan kontak dengan akar yang tumbuh ketika pupuk hayati tersebut diberikan melalui permukaan tanah (Afanador-Barajas et al., 2021). Media

\section{DAFTAR PUSTAKA}

Afanador-Barajas, L. N., Navarro-Noya, Y. E., Luna-Guido, M. L., and Dendooven, L. (2021). Impact of a bacterial consortium on the soil bacterial community structure and maize (Zea mays L.) cultivation. Scientific Reports, 11: 13092.

Bhattacharjee, R. and Dey U. (2014). Biofertilizer, a way towards organic agriculture: a review. African Journal of Microbiology Research, 8(24): 2332-2342.

Borriss, R. (2011). Use of plant-associated Bacillus strains as biofertilizers and biocontrol agents in agriculture. In $\mathrm{D}$. K. Maheswari (ed.), Bacteria in agrotebiology: Plant growth responses. (pp. 41-75) Berlin: Springer-Verlag.

Edi, S. (2019). Analisis faktor-faktor yang mempengaruhi perilaku konsumen terhadap permintaan jagung pada tingkat rumah tangga di Kecamatan Pasarwajo Kabupaten Buton. Intelektiva: Jurnal Ekonomi, Sosial dan Humanoria, 1(5): 90-100. pembawa yang sesuai juga akan mempengaruhi kualitas dari pupuk hayati yang digunakan (Bhattacharjee and Dey, 2014).

Penggunaan pupuk hayati dapat berperan atau tidak berperan dalam meningkatkan pertumbuhan tanaman jagung. Beberapa hal yang harus diperhatikan dalam aplikasi pupuk hayati seperti komposisi mikroorganisme dalam pupuk hayati, jenis tanaman, tingkat pemupukan, dan cara pemberian pupuk ke tanaman.

Fukami, J., Cerezini, P., and Hungria, M. (2018). Azospirillum: benefits that go far beyond biological nitrogen fixation. AMB Express, 8(73):1-12.

Jeong, H., Choi, S. K., Ryu, C. M., and Park, S. W. (2019). Chronicle of a soil bacterium: Paenibacillus polymmyca E681 as a tiny guardian of plant and human health. Frontier in Microbiology, 10: 1-16.

Jnawali, A. D., Ojha, R. B., and Marahatta, S. (2015). Role of Azotobacter in soil fertility and sustainability-a review. Advances in Plants and Agricultural Research, 2(6): 250-253.

Laditi, M., Jemo, M., Nwoke, O. C., and Abaidoo, R. C. (2012). Evaluation of microbial inoculants as biofertilizer for the improvement of growth and yield of soybean and maize crops in savanna soils. African Journal of Agricultural Research, 7(3): 405-413.

Maulana, Z., Zaitun and Jumini. (2015). The effect of bio liquid fertilized application 
on the growth of two varieties of maize (Zea mays L.). Proceedings of The 5th Annual International Conference Syiah Kuala University (AIC Unsyiah) Sepetember 9-11. Banda Aceh. Indonesia.

Nugraha, R., Ardyati, T., dan Suharjono. (2014). Explorasi bakteri selulolitik yang berpotensi sebagai agen biofertilizer dari tanaman perkebunan apel Kota Batu, Jawa Timur. Jurnal Biotropika, 2(3): 159-163.

Patel, T., and Saraf, M. (2017). Exploration of novel plant growth promoting bacteria Stenotrophomonas maltophilia MTP42 isolated from the rhizospheric soil of Coleus forskohlii. International Journal of Current Microbiology and Applied Sciences, 6(11):1-12.

Santos, V. B., Araujo, A. S. F., Leite, L. F. C., Nunes, L. A. P. L., and Melo, W. J. (2012). Soil microbial biomass and organic matter fraction during transition from conventional to organic farming systems. Geoderma, 227231.

Savci, S. (2012). An agricultural pollutant: Chemical fertilizer. International Journal of Environmental Science and Development, 3(1)): 77-80.
Simanjuntak, A., Lahay, R. R., dan Purba, E. (2013). Respon pertumbuhan dan produksi bawang merah (Allium ascalonicum L) terhadap pemberian pupuk NPK dan kompos kulit buah kopi. Jurnal Online Agroekoteknologi, 1(3): 362-373.

Sitompul, S. M. dan Guritno, B. (1995). Analisis Pertumbuhan Tanaman. Yogyakarta: Gadjah Mada University Press.

Sudiarti (2017). Efektivitas biofertilizer pada pertumbuhan tanaman kedelai edamame (Glycin max). Jurnal SainHelath, 1(2): 46-55.

Vandenberghe, L. P. S., Garcia, L. M. B., Rodrigues, C., Camara, M. C., Pereira, G. V. M., de Oliveira, J., and Soccol, C. R. (2017). Potential application of plant probiotic microorganisms in agricultural and forestry. AIMS Microbiology, 3(3): 629-648.

Waghunde, R. R., Shelake, R. M., Sabalpara, A. N. (2016). Trichoderma; a significant fungus for agriculture and environment. African Journal of Agricultural Research, 11(22): 19521956. 